\title{
5
}

\section{Can Classical Location Theory Apply to Sea Space?}

\author{
Jacek Zaucha
}

\section{Introduction}

Economists assume that consumer preferences are usually revealed through the market mechanism in which demand and supply are confronted. A competitive market is believed to ensure efficient allocation of resources providing the highest level of consumer utility and producer profit. Both are assumed to behave in an entirely rational way, and furthermore, it is also assumed that their choice is immediately mirrored in the changes of the prices of goods and factors of production. However, these beneficial market outcomes might become suboptimal due to time-inconsistent preferences, information asymmetries, unequal market power of some producers or consumers, the occurrence of externalities or the non-excludable and non-rivalrous character of consumption of some goods or services (i.e. public goods). Such a situation is known as market failure. For this reason, in some cases, the market is supplemented with the public choice mechanism under which democratically elected public bodies aggregate consumer preferences and reveal them (impose them) in the form of various administrative decisions and economic incentives (e.g. subsidies, taxes, auctions for location permits). Marine spatial planning (MSP) is part of public choice.

This chapter compares the two mechanisms outlined earlier (market and public choice) for the allocation of marine space to various uses. Both of them

\section{J. Zaucha $(\bowtie)$}

Institute for Development and Maritime Institute, University of Gdańsk, Gdańsk, Poland

e-mail: j.zaucha@instytut-rozwoju.org 
are assumed to shape spatial patterns in the sea. The chapter aims at answering the question whether MSP can neglect market outcomes and to what extent the market can neglect MSP. The market process is analysed within the framework of location theory, a well-established branch of economics. First, different location models based on market principles are analysed in order to find the most suitable one for maritime space. Second, Thünen's ${ }^{1}$ way of thinking is applied in order to predict hypothetical spatial development patterns at sea that might emerge under market rule. Third, these results are confronted with existing patterns of offshore spatial development in Poland. Fourth, the outcomes of administrative decisions are added to this picture. The final part of the chapter is devoted to the discussion of the interplay of market and public choice (MSP) as mechanisms shaping spatial development offshore.

\section{Location Theory}

As noted by Fujita (2010), classical location theory emphasizes market-driven mechanisms that shape spatial patterns, that is, spatial development. According to Blaug $(1985,614)$, the theory of spatial economics ${ }^{2}$ focuses on area and distance. Contemporary research in this field adds new characteristics to the understanding of area, such as density (intensity of economic activity per square $\mathrm{km}$ ) or institutional tissue (World Bank 2009). Spatial economics, using an economic approach, explains how space (e.g. distance, economies of agglomeration) affects the decisions of economic agents. It contains two groups of models explaining spatial development: those assuming an a priori existence of certain nodal points in a space of higher economic density (markets, production or extraction locations) and those models treating space as fully homogeneous and isotropic, where only an interplay between economic factors diversifies its economic density. In both models, economic agents act in their own self-interest. Firms choose locations to maximize their profits, and consumers choose locations maximizing their utility level. Those choices manifest themselves in the so-called spatial/ground/location rent (or bid rent), that is, the amount of money the users of a given part or land are willing to pay for earning the right to its usage. The amount corresponds to the profits or utility provided by a given piece of land.

\footnotetext{
${ }^{1}$ Johann Heinrich v. Thünen is a founder of spatial economics. In the nineteenth century, he developed the first rigorous approach to explain the formation of spatial patterns (concentric rings of various types of agriculture crops) around a pre-set market for agricultural products.

${ }^{2}$ Spatial economics covers also location theory.
} 
In the first class of models, rent refers to the distance and net profits derived from the usage of a given piece of land, that is, the revenue from a given piece of land minus the costs, including transport costs, the latter of which depends on the distance to suppliers and points of sale. In some models, instead of revenue, there are only costs. In these models, the a priori assumptions about the organization of space allow for the use of the concept of perfect competition, ignoring the fact that the cost of covering distance might result in monopolistic competition or even an oligopoly market. The second class of models, in its reasoning, has to add an economic mechanism that leads to the distortion of spatial homogeneity. As a rule, it is assumed that there are interactions between two forces shaping the socio-economic space: the centripetal force that favours concentration (e.g. economies of agglomeration) and the centrifugal force causing dispersion (e.g. costs of covering the distance). Therefore, the second type of reasoning is quasi-dynamic or anticipatorychoice changes the underlying parameters. The first class of models (in line with their assumptions) has a quasi-static or adaptive character because choice is based on known parameters, that is, existing patterns of nodal points (although in these models spatial reallocation can occur as a result of changes in the productivity of some areas, e.g. new discoveries of natural resources or changes in the transport techniques). Thünen's and Weber's models and Launhardt's sales areas, as well as Palander's market area theory (Blaug 1985, 618-626), belong to the first class of models. Christaller's central place theory (1933) and Lösch's economic region (1940), however, have elements of the second approach even though they are situated in the first class of models. However, both in Lösch and Christaller, the a priori assumption is that population is distributed evenly in space. In the second class, we have Isard's regionalism (1956) and new economic geography (Krugman 1991a, b; Fujita et al. 2000). Most of the aforementioned models are microeconomic and emphasize business decisions, although regionalism and even Christaller's theory are characterized by a macroeconomic approach. Only the models of the new economic geography, submerged in the realities of monopolistic competition that results from the very nature of space, belong to the class of formalized equilibrium models. These issues are described in detail in the literature consulted (Blaug 1985; Ponsard 1988; Zaucha 2007).

In the models based on monopolistic competition, the aforesaid economies of agglomeration (agglomeration externalities) play a decisive role. One of the most comprehensive attempts to examine them is to be found in Fujita and Thisse (2002). The authors state that the "fundamental trade-off of a Spatial Economy" are economies of scale and transport costs (Fujita and Thisse 2002 , 93). Increasing returns, along with an increase in production scale, are 
the result of externalities stemming from proximity to other businesses, supply chain efficiency and customer perceptions, as well as more efficient (better specialized) labour resources (Fujita and Thisse 2002, 98). All this contributes to the economies of agglomeration that, according to McCann $(2013,54-56)$, include internal returns to scale (which require the concentration in a single place of significant capital and labour inputs), economies of localization (physical proximity of enterprises in the same sector) and economies of urbanization (proximity of enterprises of various sectors). Their appearance was recognized by Marshall $(1920,225)$ at the beginning of the previous century. According to the new economic geography (Krugman 1991b, 101-113), such economies are reinforced by the influx of workers, encouraged by the relatively higher wage levels in places where such externalities emerge. This in turn allows for an increase in the number of services and goods produced in a given location, which is important in the situation of consumer preferences for variety. As a result, there are processes of catastrophic ${ }^{3}$ agglomeration followed by a spatial bifurcation of the economy. However, they are countered by the costs of overcoming the resistance of space (e.g. transport costs). When they are high, the local market does not allow for the emergence of large business entities as they would not have the sufficient market to be served by them. The economies of scale would reduce costs and prices, but this effect would be offset by the high costs of supplying consumers. Production has to take place close to the consumer, and consumers do not look for employment outside of the their place of residence, because of the low concentration of production in space. Only the falling costs of trade allow the economies of agglomeration to become visible and concentration to become irreversible. However, in a situation of zero or very low costs of this type (Internet, relatively low transportation costs, telework), the economies of agglomeration spill out. They are no longer limited to certain places of high density of economic activity since, with no distance, they work everywhere (skilled workers can work through Internet regardless their location, ideas and know-how easily spread out in the space). Hence, dispersion tendencies may emerge. Here the favourable factor is the lower wages outside the existing production centres and the non-mobile local assets, that is, territorial capital (Zaucha 2007, 64-66). As Przygodzki points out $(2016,84)$, "Functional and relational elements are the most recent and most interesting development factors" of space. Hence, he points to the important role of "social absorption, diffusion and processing of knowledge and experience, common learning, establishing and maintaining

\footnotetext{
${ }^{3}$ Catastrophic means that firm or consumer location changes in a discontinuous way.
} 
territorial co-operation.” In a similar vein, Johansson and Quigley (2003) emphasize that networks of assets dispersed in space can be a good substitute for agglomeration processes. Paradoxically, Christaller's elaboration of the theory of central places, more than 80 years ago, arose from very similar assumptions to those described earlier. In his reasoning, there are also centripetal forces in the form of minimum sales thresholds (minimum number of consumers ensuring profitability of production) and centrifugal in terms of reach (the maximum distance a consumer is willing to travel to buy a given good or service).

Unfortunately, contemporary economics' inspiring approach to the economic mechanisms of spatial development (economies of agglomeration and distance) cannot, to date, be applied to maritime space (at least to sea areas). From the entire array of elements pertaining to the new economic geography mainly local assets (territorial capital) and the cost of transport also appear at sea. The economies of agglomeration, even if they do occur in marine space, have very high transaction costs ${ }^{4}$ or barriers of nonconformity and temporal friction. This is due to the specificity of this space, characterized, for example, by the lack of inhabitants, positive externalities (related mainly to costs of shared use of resources) and the differences in market power among the users of marine space.

\section{The Location Theory Applied to Sea Space}

Referring to marine space, one may think that it would be appropriate to consider the return to models which accept the already existing (a priori) setup of human activities. This is plausible because development of the terrestrial structures (e.g. port cities, transhipping terminals) related to sea exploitation predates maritime spatial development. The "nodal" elements appeared ashore while the seas constituted economic space functionally linked to them. The most promising model in this situation appears to be a relatively old agricultural one developed by Thünen which assumes the existence of a pre-existing marketplace. This model is still used in the analysis of the spatial development of cities (McCann 2013, 107-153).

The legitimacy of such a choice is based on the fact that there are already established "sea gateways" on land aiding the economic activity of people at sea. They are characterized by a specific hierarchy similar to Christaller's

\footnotetext{
${ }^{4}$ The possibility of lowering them is discussed in the concluding part of the chapter.
} 
pattern since certain gates serve many functions (e.g. ports are bases for sailing, fishery, wind power stations, marine-mining or marine tourism), while others, for example, beach resorts or piers, serve a limited range of functions. The difference in relation to Christaller's concept of central places is that multifunction centres (gates) need not support the sea activity that is typical for their monofunctional equivalents (e.g. port cities do not always have beaches). All of the above calls for a more thorough consideration of models proposed by Thünen and Weber ${ }^{5}$ since other models seem to have lesser explanatory potential. ${ }^{6}$

The essence of Thünen's concept is an exogenously given sales market and two parameters shaping spatial patterns around it: net benefits per unit area of the cultivation of different agricultural products and costs of their transportation. Near the market area, there are cultivated goods that yield high profits and have high transportation costs. Further away, there appears to be a place for less profitable and expensive farming, while at an even greater distance, those goods appear that are least effective at using the soil but also cheapest in transport per unit. The result is the appearance of Thünen's famous location circles (Blaug 1985, 619). A number of assumptions were made in the model, the most important of which deal with constant economies of scale, homogeneous soil fertility, lack of restrictions on the side of productive resources that are available everywhere in the same proportions and so on.

It seems that location rent in maritime space is shaped in a similar manner. The Thünen model foundations are generally fulfilled. A certain problem in this respect is the heterogeneous productivity of the space resulting from natural conditions, such as the existence of deposits, fishing grounds or areas particularly predestined for offshore wind energy. However, a similar dilemma appears on land, which was analysed with reference to urban space and its ecological values by McCann $(2013,127)$. This may bring about a concavity in certain fragments of the rent function, which means that functions of the rents can intersect at several points (different economic activities are not located any longer in the same distance from the city centre). Consequently, similar manners of reaping benefits from the sea may appear in several zones at various distances from the land gateways. However, if maritime space lacks

\footnotetext{
${ }^{5}$ At the beginning of the twentieth century, Alfred Weber formulated the "least-cost model" of location of industrial plant, allowing him to explain industrial location decisions at a macro-scale.

${ }^{6} \mathrm{Lösch}$ is concerned with the economic region and, above all, the effects of spatial competition of producers while assuming a uniform distribution of population. This condition is not fulfilled at sea. There are no Launhardt markets or Palander's market areas at sea. These theories would be able to explain the location of certain land-based marine management entities.
} 
suitable characteristics, it may not be used for economic purposes at all. This is similar to the situation on land, where under certain circumstances, poor soil quality may result in land lying idle within a certain distance from the centre (negative location rent). This results from the fact that the rent curve in this situation becomes a discontinuous, non-monotonic ${ }^{7}$ function (Ponsard 1988, 39).

Taking all this into account, it is plausible that market forces at sea could lead to the formation of Thünen's semicircles (assuming that the coastline is straight) around the sea gateways (ports, bathing beaches, etc.). The first circle includes functions typical for their proximity to the port (anchorages, dumping sites), while others will be farther away, for example, wind energy at sea, and even farther-fishing. However, the denser spreading of bathing areas will result in a narrower strip for bathing along the coast determined by the overlapping half-circles of traditional coastal tourism (Fig. 5.1). If necessary, however, they will have to allow for other ways of using the sea, ones that have a higher degree of location rent (such as port complexes).

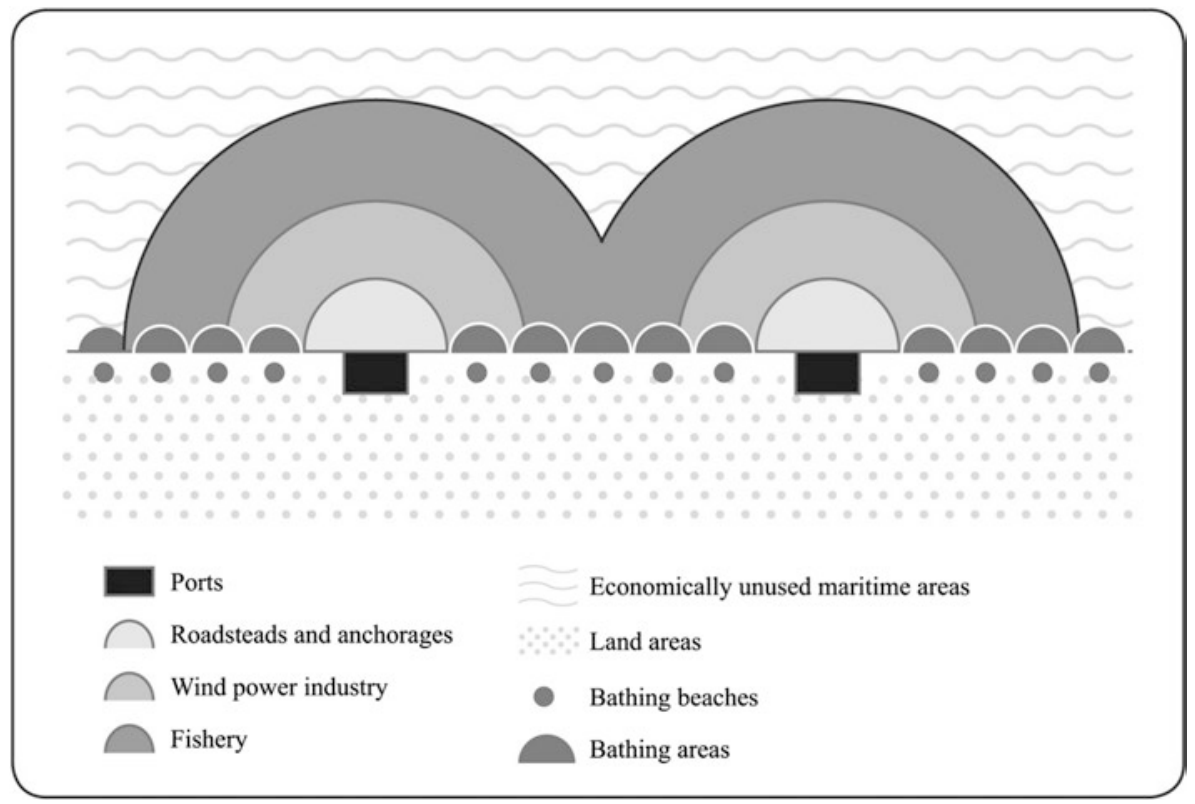

Fig. 5.1 Location semicircles (in sea areas) around the sea gateways of different importance (Zaucha 2018)

\footnotetext{
${ }^{7}$ The function is non-monotonic when it is growing at certain intervals and decreasing at other intervals.
} 
Taking into account differences of marine areas' suitability for various purposes (i.e. its non-homogeneity), location circles will not be regular in shape due to dissimilarities in the productivity of different marine areas. In certain circumstances, economic activity might be spatially limited, for example, where a possibility exists of obtaining specific ecosystem services or abiotic benefits (gravel extraction is only possible in areas with gravel deposits). Location rent will nonetheless play a significant role. For example, coastal defence, if applied to densely inhabited or economically developed pieces of coast, usually offers larger benefits in comparison to gravel extraction so that coastal defence can even stop commercial gravel extraction due to rent differences. If the rent associated with renewable energy sources or mining is higher than what can be derived from fishery, the latter activity must operate at a further distance (Fig. 5.2).

Some of the patterns of maritime spatial development are dependent on several land gates at the same time. For example, facilities of the offshore wind power industry have to be located at a proper distance to service ports and, especially, to shore power connections (connecting wind farms to the power grid) which may not be at the service ports. This placement can be linked to Weber's theory which is based on his analysis of the best potential location for a production facility aiming to minimize transportation costs (access to

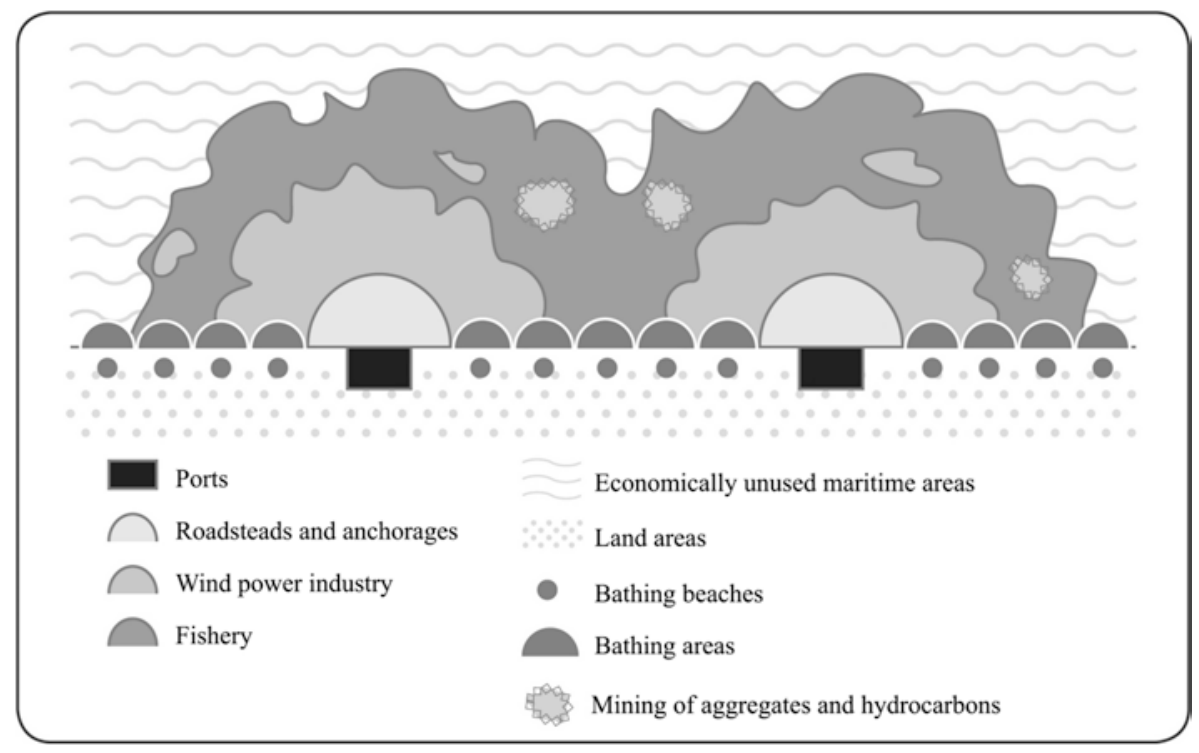

Fig. 5.2 Location zones in sea areas taking into account the phenomenon of the nonhomogeneity of marine space and locations of ecosystem services and services exploiting sea abiotic assets (Zaucha 2018) 
markets and suppliers). However, it should be kept in mind that the final location of this particular facility at sea depends not only on low transportation costs but also on the differences in marine areas' levels of productivity, which is important when it comes to energy production (for this purpose, some areas are more suitable and some less so).

What is more, additional linear structures (connecting two or more gates on both sides of the sea) have to be added in order to make the model more realistic. Such structures include cables, pipelines or sea lanes. They do not follow the logic of Thünen's model. Minimizing costs between two points is a crucial factor in these situations. Of key importance is the shortest distance, and very rarely do specific features (e.g. depth, bottom habitats) of particular parts of maritime space influence their location. However, practical computation of location rent for shipping might pose a challenge since in some cases, such as navigation, it would be very difficult to attribute costs and revenues to the part of marine space that is used for that purpose (it would require detailed information of each voyage, i.e. its length and net profits).

Nevertheless, it should be assumed that zones based on Thünen's model might exist collectively with linear areas (Fig. 5.3). Due to the multidimensional character of maritime space, in some situations, the summing of various location rents might occur since many users can use the same sea space simultaneously (under certain conditions, navigation does not impact

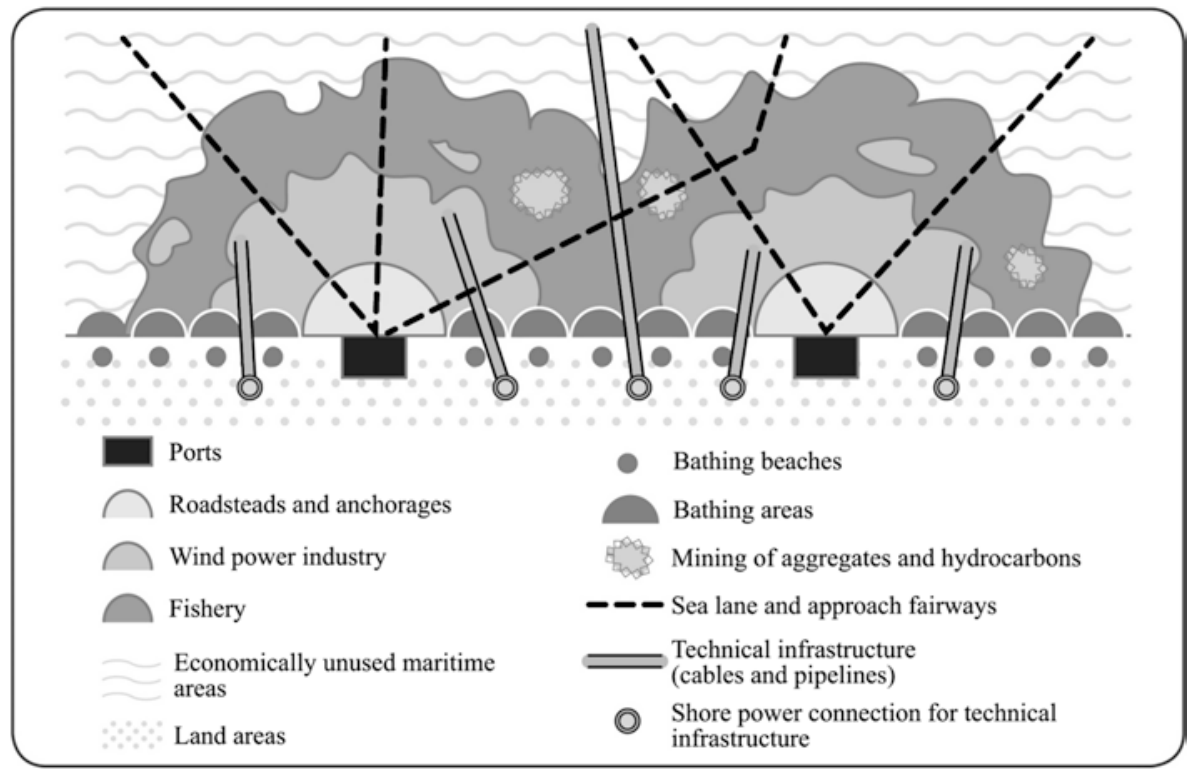

Fig. 5.3 Location zones in sea areas along with linear structures (Zaucha 2018) 
pipelines negatively, and cables are outright necessary for the development of the wind power industry, representing synergy). In other situations, changes in the market might allow for the highest rent through the selection of appropriate forms of economic activity. For example, building wind farms may force some changes in sea transport lanes.

The picture presented seems pretty static. However, along with the intensification of the blue economy and blue growth, new functional regions will appear at sea holding the possibility of redefining such regions in the future. Finally, it may happen that the sea-land influence occurs in the opposite direction (from sea to land), thus becoming an economic incentive to create new maritime gateways on land. That could lower the costs of transportation. ${ }^{8}$ For example, it is very likely that an increase in the popularity of yachting may result in establishing new marinas. Demand related to ferries can cause more ferry terminals in new locations. The critical mass of particular forms of using marine assets should be the next important factor in the context of presenting models of market processes inducing changes in maritime spatial development. Potentially, new gateways servicing sea space might appear offshore and perhaps some of them could offer economies of agglomeration.

The deductive approach presented earlier finds support in the empirical material gathered in the course of the preparation of a maritime spatial plan for Poland. Prior to the emergence of MSP activities in Poland, marine space was developed according to the demand of investors and sea users. The outcome is visualized in the form of the map of existing and planned sea uses of Polish maritime areas in the report entitled Study of Conditions of Spatial Development of Polish Sea Area (Zaucha et al. 2016). ${ }^{9}$ The map confirms a picture that the above theory would also predict. Port-related activities, traditional tourism and recreation and offshore wind farms are sorted according to their distance from the shore. For example, for offshore wind farms, depth seems to play an important role. For other activities like fishing or oil extraction, natural conditions and oceanographic characteristics seem to be decisive. Surprisingly, environmental protection tends to cluster near the shore as well, possibly due to the photic conditions there and a larger amount of easily available information on birds and habitats. Thus in economic terms, the

\footnotetext{
${ }^{8} \mathrm{New}$ investments of this type are limited by their costs which should be lower than the discounted (on the day of the opening of such gateways) amount of benefit presented in the form of lower transportation expenses or an increase of existing revenues or even the creation of new ones obtained from new forms of exploiting sea areas.

${ }^{9} \mathrm{http} / /$ www.umgdy.gov.pl/wp-content/uploads/2015/04/INZ-UM_Map1_Present_and_future_use. png.
} 
photic zone produces more benefits (ecological values) in comparison to other types of marine space. The ultimate monetary value of those benefits, however, depends on the value system of a given society.

In general, all this roughly confirms the importance of location rent as a guiding location force and its dependence on the distance to the land gateways servicing the sea areas at least for some sea uses.

\section{$4 \quad$ Maritime Spatial Planning as a Public Choice Mechanism for Marine Governance}

Maritime space as a precious development asset (natural capital) is considered to be a perfect example of market failure. The main reason is the lack of private ownership restricting the proper functioning of prices in their function of balancing demand with supply. Maritime space is considered to be a common-pool resource (Ostrom et al. 1994, 7), which is characterized by competitiveness of consumption and the inability to exclude anyone from it, that is, non-excludability (Daly and Farley 2011, 169). There is a lack of clearly defined property rights or those rights are acting in a limited way. According to game theory, it is profitable to maximize individual payouts here and now at the expense of the resource itself. In addition to the above, marketdriven allocation of marine space suffers from information asymmetries, importance of externalities provided by the marine ecosystems and the unequal market power of some sea users. Moreover, status differences of particular users of maritime space may be perceived as a problem. The offshore wind industry, for example, has to bear the cost of functioning at sea, which has a substantial impact on its services' prices. Other users, such as sailors, are allowed to access the sea for free. This disrupts the effective development of maritime space by using market mechanisms. One should also keep in mind that maritime space should be maintained for future generations that are not able to reveal their preference at the market. Due to all these reasons, marine space requires collective governance mechanisms. In economics, these are called public choice mechanisms and are associated with administrative decisions. MSP forms its core.

Public choice (Stiglitz 1999, 157-188) is a form of aggregating individual preferences into collective preferences in cases of market failure. It entails joint decision-making in a democratic manner; that is, it involves voting. As a consequence, selected people are entitled to make specific decisions concerning public goods (including key components of social life, such as social justice, 
biodiversity). They are also entitled to choose the methods used in supporting or neutralizing externalities in some special situations of market failure. The act of voting provides the necessary social legitimization. Democratic decisionmaking is not the only means of ensuring public choice, but it is the dominant model in Europe. Without such legitimization, decisions made by the public administration would take a voluntaristic form. The decision-making body, in a democratic process, is able to assign some elements of aggregation preferences to the executive body. One should keep in mind that this is a slightly simplified picture of public choice, as in reality, public choice governance is composed of myriad interactions between various decision-making and executive bodies, including stakeholders, with and without jurisdiction both in vertical and horizontal dimensions (e.g. Hassler et al. 2018). The outcome is agreement on the key societal goals and their execution within a framework of various policies.

The first stage of public choice is, most frequently, related to axiological matters, that is, determining goals that should be achieved in compliance with the social welfare function (Stiglitz 1999, 98), provided there are no market mechanisms responsible for achieving those specific goals (such as inherited altruism). The social welfare function contains every significant value, not only public justice but also, for example, the beauty of specific landscapes. Agreeing on the catalogue of key societal values allows for the establishment of methods of how the administration engages in the economic process, which means the implementation of strategies, policies and specific programmes. This impacts resource management, for example, by deciding which resources should be spent on activities outside and inside the market. There are multiple options:

- Modification of the market processes by tax systems (fees associated with the usage of maritime space or subsidies (renewable energy sources) or other activities (e.g. restoration of information symmetry by the publication of research results))

- Allocation of public funds on goals that are not included in market mechanisms (e.g. navigational signs that guarantee safety of navigation, social capital, social justice by supporting fisheries organizations)

- Changes in producer and consumer behaviour by legal regulations and various forms of rationing or administrative regulations and by supporting the formation of proper institutions (e.g. binding maritime spatial plans, licensing, arrangement, rules and conditions of using common resources)

- Changes in producer and consumer behaviour by educational activities, capacity building and awareness raising 
In the literature, it is generally assumed that the purpose of MSP is sustainable development, although the importance given to individual dimensions of sustainable maritime development varies (see: Saunders et al. 2016). The European Commission is also explicitly in favour of this type of development, as expressed in various documents including the Maritime Spatial Planning Directive (EC 2014a, Article 5). Many documents issued by the European Commission refer to sustainability in their titles, for example, the Sustainable Blue Growth Agenda for the Baltic Sea Region (EC 2014b). It is generally accepted that sustainable development encompasses ecological, social and natural spheres in their specific spatial dimensions (Dühr 2011). The environmental dimension can be related to the Marine Strategy Framework Directive (MSFD; EC 2008), the economic dimension to Blue Growth strategies (EC 2014b; Varjopuro et al. 2015, Schultz-Zehhden et al. in this book) and the social dimension to stakeholder participation and knowledge building (Zaucha et al. 2017). Despite some strong critique, sustainability still seems to be politically attractive, as evidenced by the adoption in 2015 (23 years after the first Earth Summit) of the document "Transforming Our World: the 2030 Agenda for Sustainable Development" (UN 2015). Goal 14 has a clear reference to sustainability at sea.

The ecological dimension of sustainable development can also be expressed as resilience, understood as an ability of ecosystems to absorb shocks, various pressures and disturbances by renewing, reorganizing and developing while maintaining their essence and preceding functions (Walker et al. 2004). Davoudi et al. (2016) propose an expanded understanding of the notion: evolutionary resilience, focusing on the management aspect. In this theory, in addition to persistence, which is concerned only with ecosystems, flexibility plays a key part (understood as an ability of an ecosystem to choose alternative paths of development), as do resourcefulness, transformability and, above all, readiness (preparedness) to meet challenges. Weig (2016), dwelling on evolutionary economic geography and complexity theory, also explains how path dependency can avoid lock-ins through learning processes, building up resilience as an emergent pattern. Thus understood, resilience is both a paradigm and a development pattern of broader socioecological systems, and thus a complement to sustainable development, since the transformational element of the resilience concept brings with it dynamism and adaptivity.

Another alternative to sustainable development or evolutionary resilience as a public choice key objective may be the goal of minimizing spatial conflicts at sea. This makes sense in the case of so-called win-win solutions. A spatial order emerges, but this can encourage more intensive use of maritime space, which in turn makes this kind of approach no longer robust. 
Marine governance as a function of conflict minimization has been prevalent in most coastal countries until recently. This era, however, has ended with the emergence of new forms of sea use and more intensive use of marine space that would require trade-offs.

Other goals frequently applied in relation to terrestrial spatial development such as quality of life, territorial cohesion or spatial integration (Costanza et al. 2008; Zaucha and Szlachta 2017, 19-22; Doucet 2013) appear to be of lesser importance at sea due to the limited presence of human beings there or the lack of clarity regarding the goals' substance and content, particularly quality of life (cf. Bok 2010). These goals should be treated as part of broader development paradigms, that is, sustainable development or resilience. Such an approach to quality of life is, for example, seen in OECD (Organisation of Economic Co-operation and Development) research $(2013,29)$.

All the axiological issues mentioned earlier are only the tip of the iceberg in terms of problems arising from public choice in the context of maritime spatial development. Even assuming that risk aversion, typical for public authorities, has been overcome and that authorities have managed to successfully aggregate private preferences into the public ones regarding maritime space, the public choice process immediately encounters several other challenges.

The first dilemma concerns temporal aspects of the aggregation of individual preferences. For instance, the desirable proportions of elements constituting sustainable development might evolve in time. These proportions depend on social prosperity and social awareness. During processes related to public choice, organized groups of stakeholders, who may convince authorities that they are speaking for the entire society and all those concerned, can emerge as a threat. The ease of this operation is proportional to the magnitude of transaction cost associated with the participation in the public choice processes and the magnitude of the individual loss perceived by non-organized individuals as a result of non-resisting the vested interests.

The second issue is associated with the multilevel character of public choice. Preferences aggregated locally may differ from those at regional, national or EU level. Externalities of energy production can serve as an example. Offshore energy can be treated as desirable at national level but can be opposed at the local level due to landscape pollution. This applies not only to EU shared policies but also to the exclusive ones. The Common Fisheries Policy puts emphasis on the sustainable use of resources of marine biota, while on the local level there are frequent demands for additional maritime space for fishers in order to protect their cultural role as part of a specific landscape and touristic values (externalities). Sometimes, legislators might even consider local and regional 
preferences more important than national ones; however, as described earlier, this might easily serve the needs of vested interests.

The third potentially faulty element is associated with the agency dilemma (principal-agent problem) (Mitnick 2006). Legislature aggregates public preferences with regard to marine space, but its ability to control the executive bodies is limited. This is because the latter group often has more information in certain fields of knowledge, and therefore, decision-makers have various problems evaluating the agents' level of involvement and reasons for failure in this context. In such cases, the phenomenon of subjective risk-taking-also known as moral hazard-can occur. Another problem is adverse selection, that is, an agent's choice to act in a negative way (from the principal's perspective) on the basis of information that is being held back by them. The result is insufficient effort of the executive authority focusing on activities based on self-interest.

The fourth problem relates to frequent changes in terms of goals, preferences and directions taken during spatial development. Public choice is characterized by its dynamic nature. There is no denying that voters' preferences change in response to stimuli, such as the available information or the state of the economy, and that this causes changes in policies and programmes. Nonetheless, private investors require a predictable economic horizon for their decisions, especially when the long-time rate of return is concerned. Distrust towards the policy stability of a given country or region may discourage investments. As a result, the most desirable patterns of maritime spatial development might not be realized even though they may have been previously declared (in the course of the public choice) and investment from the public sector may be necessary to fill in the gap. Economic praxis shows that investors start to act if, at the time of bearing the cost, the discounted future profits are higher than the discounted costs themselves. Risk provokes a more conservative assessment of profits, while uncertainty disrupts this process.

The fifth problem is related to deficiencies in putting forward aggregated public choice preferences towards maritime space. The above-mentioned instruments might appear insufficient and the various governance processes might not sufficiently reinforce each other. For instance, MSP can reserve areas for offshore renewable energy, but the absence of adequate feed-in tariffs or limits in transmission capacities of a public grid might make this effort futile.

All these situations are related to governance failure. This does not mean that public choice has no real influence on the way maritime space is developed. On the contrary. It is only thanks to better or worse public choice decisions that some functions can be assigned to sea space, such as: 
- Preservation of environment (externalities, public good)

- Landscape protection (public good)

- National defence (public good)

- Underwater cultural heritage (externalities)

- Living organisms' well-being (common resources)

- Basic scientific research (public good)

- And those left unused for the use by future generations (inter-generational justice)

This situation is presented in Fig. 5.4.

By doing this, MSP adds a social-spatial rent to the private rent perceived by the business sector. Such rent is related to important social values (e.g. sustainable development), positive and negative externalities and can be described as an expression of their importance revealed through MSP in comparison to a pure market approach. From a purely economic perspective, MSP is a public choice process. Its essence is in the aggregation of preferences of individuals towards maritime spatial development and the shaping of

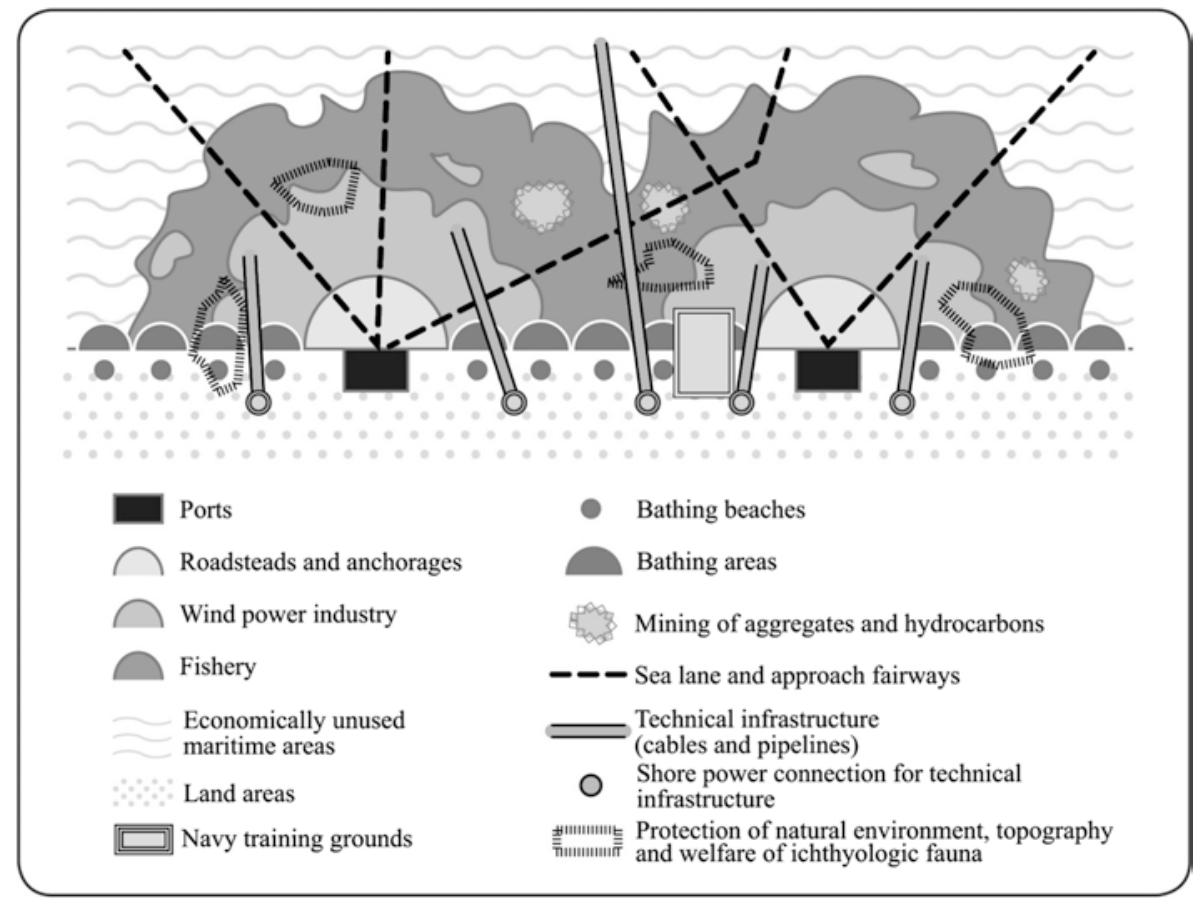

Fig. 5.4 Influence of public choice on the market processes that together shape maritime spatial development (Zaucha 2018) 
public decisions on the allocation of sea space to these preferences in a situation of market failure. However, as described earlier, it can fulfil its role provided that other marine governance regimes are properly integrated with or within MSP (see also Chap. 6 in this book).

\section{$5 \quad$ Interplay Between Maritime Spatial Planning and Market Forces}

In reality, maritime spatial development is shaped by both public choice (MSP in particular) and market mechanisms. This fact has been widely recognized by maritime stakeholders, for example, in Poland. Out of 70 Polish MSP stakeholders examined by Ciołek et al. (2018), the vast majority view maritime spatial development as an outcome of such a combination. Only a few (eight) declared that MSP should be solely driven by the concerns and ideas of maritime administration and even fewer (five) declared that the market should have a final say in shaping solutions of MSP. These preferences were independent of the level of knowledge on MSP. Here one can see a kind of broad societal consensus, at least in Poland.

According to the existing regulations (EU 2014) in the EU, MSP, along with some other administrative processes (e.g. Natura 2000 management plans, some international conventions like United Nations Convention on the Law of the Sea-UNCLOS), was assigned, at least in formal terms, with a leading role in shaping maritime space. However, this does not preclude the market forces' real influence on the planning outcomes.

By observing MSP in several EU countries, one can easily notice the significance of such forces and the importance of location rent. In the UK, Germany and Belgium, offshore energy has received a prominent role in spatial plans. In all existing plans, particular attention is paid to shipping. Both users offer one of the highest location rents according to estimates of their Gross Added Value (Ecorys 2012) in relation to the space occupied. The exception to this rule is environmental protection as a genuine public choice decision under EU governance, the latter being a regime that also plays an essential role despite low private location rent. However, its social rent (private rent plus value of externalities) seems very high as well. Thus, as on land, on the one hand, MSP acknowledges some market processes (due to important benefits of key MSP stakeholders), while on the other, it corrects some key market failures (e.g. by internalizing externalities within the allocation process, as is the case with environmental protection). Another example 
of the importance of social rent is the decision in the Polish MSP to pay special attention to the spatial needs of artisanal fishers. Despite its limited profits, this sector has been considered as important and deserving of access to marine space due to symbolic and cultural reasons (i.e. due to its high social rent).

The key problem is, however, that MSP, in many cases, acts under uncertainty. The monetary value of externalities is unknown, and the democratic decision-making in many cases fails to reveal clear preferences to some uses (as it has been done with regard to environmental protection via MSFD). Thus, learning by doing and provoking public debate are the only feasible methods for planners who, as a rule, have no authority to decide on values and societal goals under public choice (see also Chap. 9 in this book).

The question posed at the beginning regarding the relevance of classical location theory in understanding maritime spatial development should therefore garner a positive answer. Nowadays in the EU, both market and MSP shape maritime spatial development. Classical location theory, despite all its shortcomings, might offer an interesting starting point for considering how it plays out in practice. Its strength is in encompassing economic considerations with regard to the usage of maritime space combined with a pre-set structure of existing sea gateways on land. Thünen's model can help in predicting good candidate areas for certain economic development zones in a plan. Such an approach should allow the designation of e.g. investment zones in order, perhaps, also to promote economies of agglomeration.

However, in contrast to Thünen's specific time period, nowadays the situation seems much more complex and dynamic. Game theory and strategic behaviour of developers should also be considered. Also, a key difference is that MSP might become a proactive agent in influencing all cardinal features of Thünen's interplay between costs and revenues. For example, it can influence market mechanisms by the wise management of distance and the development of terrestrial gateways servicing the sea areas. Thus, spatial planning can influence behaviour and prompt the decisions of private businesses. For instance, in Poland the completion of a new motorway network will create economic incentives that might result in the construction of a new large port in the central Polish coast (Komornicki 2015).

Moreover, other more sophisticated mechanisms of influencing market processes are also available for MSP. As pointed out by Zaucha (2007), spatial planning can influence investor decisions: 
- by creating expectations of a given course of development in the future (thus, the planning process might cause the location decisions of the private sector even without public investments [in transport or in sea gateways], provided that the perceived benefits [i.e. those resulting from planning] are sufficiently high).

- by revealing important information about the space and/or diminishing risk of conflicts since all of these lower investment costs.

More on this topic can be found in Schultz-Zehden et al. in this book.

The question remains as to what extent MSP can foster economies of agglomeration. As pointed out by the MUSES (The Multi-Use in European Seas - a Horizon 2020 funded project) project, ${ }^{10}$ MSP can help in overcoming high transaction costs of multi-uses that are considered to be new and more efficient ways of exploiting marine space. Multi-use in the long run leads to an increase in the productivity of labour and capital (e.g. higher revenues from usage of ships both for servicing offshore wind farms and mariculture co-located with them). This, in turn, might result in a clustering of economic activities in marine space. Additionally, other features might lead to a similar outcome (e.g. bathymetry, availability of light). However, it is not clear whether such islands of higher productivity in the sea would underpin a cumulative causation, that is, forward and backward linkages. On the one hand, a combination of offshore energy and mariculture can attract or even foster entirely new uses, such as tourism related to offshore industries or the construction of electricity filling stations for autonomous ships but, on the other hand, this might increase the cumulative pressure on the sea ecosystem that is essential for the provision of numerous marine ecosystem services. Thus, the environment can pose some limits to the concentration of Blue Growth. Moreover, sea industries share the same value chain only to a limited extent. Many up- and downstream industries connected to the marine sectors are much more productive on land than on sea. The most intriguing question is, therefore, the possibility of the appearance of network agglomeration economies at sea and land. For instance, multi-uses may foster, in an indirect way, learning processes and, thus, agglomeration economies, because people from different sectors need to talk to one another in order to understand the needs of others and to cooperate. All these questions deserve more systematic answers and further research. They will pave the way to a research agenda of marine spatial economists in the years to come. Thus, the future of marine spatial economics resides not only in understanding the

\footnotetext{
${ }^{10}$ For the project, please consult https://muses-project.eu/.
} 
patterns of private and social location rent and the role of MSP as a vehicle of their integration but also in better exploring interdependencies between marine sectors and their economic results as well as the ways in which MSP can contribute to their hindrance or stimulation.

\section{Conclusion}

The ultimate conclusion is that allocation of marine space requires both market and public choice mechanisms. MSP neglecting market outcomes would be hardly enforceable due to resistance of many stakeholders. However, MSP seems a key vehicle for delivering important non-market values of society, such as good environmental status, integrity of habitats or safety and security. Therefore, MSP should both support and restrict market forces simultaneously. A key challenge is to achieve a proper mix between market and nonmarket outcomes and approaches. The final mix depends on the values of a given society, and is dynamic and changes with time and prosperity level. Therefore, MSP should also be seen as a dynamic process deeply rooted in and constantly revealing key societal values, searching for an acceptable proportion between efficiency and other societal values that together constitute the social welfare function.

Acknowledgements Analyses presented in this chapter were financed by the Polish National Science Centre under the project "Economy of Maritime Space," Decision No. 2015/17/B/HS4/00918. The results are presented in Polish in Zaucha (2018). The Open Access fee of this chapter was provided by the same project. The author expresses his gratitude to the colleagues from Maritime Institute in Gdańsk, Institute for Development in Sopot and Faculty of Economics of the University of Gdańsk for support and inspiration in the course of preparation of this chapter.

\section{References}

Blaug, M. (1985). Economic Theory in Retrospect (4th ed.). Cambridge: Cam Bridge University Press, 737p.

Bok, D. (2010). The Politics of Happiness: What Governments Can Learn from the New Research on Well-Being. Princeton, NJ: Princeton University Press, 272p.

Christaller, W. (1933). Die Zentralen Orte in Suddedeutschlan. Jena: Gustav Fischer Verlag.

Ciołek, D., Matczak, M., Piwowarczyk, J., Rakowski, M., Szefler, K., \& Zaucha, J. (2018). The Perspective of Polish Fishermen on Maritime Spatial Planning. Ocean and Coastal Management. https://doi.org/10.1016/j.ocecoaman.2018.07.001. 
Costanza, R., Fisher, B., Ali, S., Beer, C., Bond, L., Boumans, R., Danigelis, N. L., Dickinson, J., Elliott, C., Farley, J., Elliott Gayer, D., MacDonald Glenn, L., Hudspeth, T. R., Mahoney, D. F., McCahill, L., McIntosh, B., Reed, B., Turab, R. A., Rizzo, D. M., Simpatico, T., \& Snapp, R. (2008). An Integrative Approach to Quality of Life Measurement, Research, and Policy. S.A.P.I.E.N.S, 1(1), 17-21.

Daly, H. E., \& Farley, J. (2011). Ecological Economics: Principles and Applications. Washington; Covelo; London: Island Press, 509p.

Davoudi, S., Zaucha, J., \& Brooks, E. (2016). Evolutionary Resilience and Complex Lagoon Systems. Integrated Environmental Assessment and Management, 12(4), $711-718$.

Doucet, P. (2013). Territorial Integration-Food for Thought. In G. Gorzelak \& K. Zawalińska (Eds.), European Territories: From Cooperation To Integration? (pp. 27-41). Warsaw: Wydawnictwo Naukowe Scholar.

Dühr, S. (2011). Territorial Cohesion and Its Impact on Sustainable Development. Baltic 21 Series, 2/2011, 14-15.

EC. (2008). Directive 2008/56/EC of the European Parliament and of the Council of 17 June 2008 Establishing a Framework for Community Action in the Field of Marine Environmental Policy (Marine Strategy Framework Directive). Official Journal of the European Union, L 164/19.

EC. (2014a). Directive 2014/89/EU of the European Parliament and of the Council of 23 July 2014 Establishing a Framework for Maritime Spatial Planning. Official Journal of the European Union, L 257/135.

EC. (2014b). Commission Staff Working Document a Sustainable Blue Growth Agenda for the Baltic Sea Region. Brussels, 16.5.2014 SWD(2014) 167 final.

Ecorys. (2012). Blue Growth Scenarios and Drivers for Sustainable Growth from the Oceans, Seas and Coasts. Final Report. Rotterdam and Brussels: European Commission, DG MARE.

Fujita, M. (2010). The Evolution of Spatial Economics: From Thünen to the New Economic Geography. The Japanese Economic Review, 61(1), 1-32.

Fujita, M., \& Thisse, J. F. (2002). Economics of Agglomeration, Cities, Industrial Location, and Regional Growth. Cambridge: Cambridge University Press, 465p.

Fujita, M., Krugman, P., \& Venables, A. J. (2000). The Spatial Economy: Cities, Regions, and International Trade. Cambridge, MA and London: The MIT Press, $367 \mathrm{p}$.

Hassler, B., Gee, K., Gilek, M., Luttmann, A., Morf, A., Saunders, F., Stalmokaite, I., Strand, H., \& Zaucha, J. (2018). Collective Action and Agency in Baltic Sea Marine Spatial Planning: Transnational Policy Coordination in the Promotion of Regional Coherence. Marine Policy, 92, 138-147.

Isard, W. (1956). Location and Space-Economy. New York: John Willey \& Sons, 350p. Johansson, B., \& Quigley, J. M. (2003). Agglomeration and Networks in Spatial Economies. Papers in Regional Science, 83(1), 165-176.

Komornicki, T. (2015). Present and Future Spatial Accessibility of the Polish Sea Ports. Bulletin of Maritime Institute, 30(1), 59-71. 
Krugman, P. (1991a). Increasing Returns and Economic Geography. Journal of Political Economy, 99(3), 483-499.

Krugman, P. (1991b). Geography and Trade. Leuven; London; Cambridge, MA: MIT Press, Leuven University Press, 142p.

Lösch, A. (1940). Die räumliche Ordnung der Wirtschaft. Jena: Gustav Fischer Verlag. Marshall, A. (1920). Principles of Economics (8th ed.). London: Macmillan, 754p.

McCann, P. (2013). Modern Urban and Regional Economics. Oxford: Oxford University Press, 408p.

Mitnick. (2006). The Origins of Agency Theory. Retrieved March 23, 2018, from http://www.pitt.edu/ - mitnick/agencytheory/agencytheoryoriginrev11806r.htm.

OECD. (2013). OECD Guidelines on Measuring Subjective Well-Being. Paris: OECD Publishing.

Ostrom, E., Gardner, R., Walker, J., Agrawal, A., Bloomquist, W., Schlager, E., \& Yan, T. S. (1994). Rules, Games and Common-Pool Resources. Ann Arbor: University of Michigan Press, 392p.

Ponsard, C. (Ed.). (1988). Analyse économique spatial. Paris: PUF 452p.

Przygodzki, Z. (2016). Kapitał terytorialny w rozwoju regionów. Acta Universitatis Lodziensis Folia Oeconomica, 2(319), 83-97.

Saunders, F., Gilek, M., Gee, K., Göke, C., Hassler, B., Lenninger, P., Luttmann, A., Morf, A., Piwowarczyk, J., Schiele, K., Stalmokaite, I., Strand, H., Tafon, R., \& Zaucha, J. (2016). Exploring Possibilities and Challenges for MSP Integration in the Baltic Sea. Stockholm: Bonus Baltspace. Retrieved March 25, 2018, from https:// www.baltspace.eu/published-reports.

Stiglitz, J. (1999). Economics of the Public Sector (3rd ed.). New York and London: W.W. Norton \& Company.

UN. (2015). Transforming Our World: The 2030 Agenda for Sustainable Development. A/RES/70/1. United Nations. Retrieved September 7, 2018, from https://sustainabledevelopment.un.org/post2015/transformingourworld/publication.

Varjopuro, R., Soininen, N., Kuokkanen, T., Aps, R., Matczak, M., \& Danilova, L. (2015). Communiqué on the Results of the Research on Blue Growth in the Selected International Projects Aimed at Enhancement of Maritime Spatial Planning in the Baltic Sea Region (BSR). Bulletin of the Maritime Institute in Gdanisk, 30(1), 72-77.

Walker, B., Holling, C. S., Carpenter, S. R., \& Kinzig, A. (2004). Resilience, Adaptability and Transformability in Social-Ecological Systems. Ecology and Society, 9(2), 5.

Weig, B. (2016). Resilienz komplexer Regionalsysteme. Berlin: Springer Publishing.

World Bank. (2009). Reshaping Economic Geography. Washington, DC: World Bank, 383 p.

Zaucha, J. (2007). Rola przestrzeni w ksztattowaniu relacji gospodarczych. Ekonomiczne fundamenty planowania przestrzennego w Europie Battyckiej. Gdańsk: Uniwersytet Gdański, 371p. 
Zaucha, J. (2018). Gospodarowanie przestrzenia morską. Warszawa: Instytut Rozwoju i Sedno.

Zaucha, J., \& Szlachta, J. (2017). Territorial Cohesion: Origin, Content and Operationalization. In J. Bradley \& J. Zaucha (Eds.), Territorial Cohesion: A Missing Link Between Economic Growth and Welfare: Lessons from the Baltic Tiger (pp. 23-47). Gdańsk: Uniwersytet Gdański.

Zaucha, J., Matczak, M., \& Pardus, J. (with 44 coauthors). (2016). Study of Conditions of Spatial Development of Polish Sea Area. Retrieved March 29, 2018, from http://www.umgdy.gov.pl/?cat=96.

Zaucha, J., Gilek, M., Hassler, B., Luttmann, A., Morf, A., Saunders, F., Piwowarczyk, J., Gee, K., \& Tusrki, J. (2017). Bonus Policy Brief: Challenges and Possibilities for MSP Integration in the Baltic Sea. Stockholm: Bonus Baltspace. Retrieved March 25, 2018, from https://www.baltspace.eu/published-reports.

Open Access This chapter is licensed under the terms of the Creative Commons Attribution 4.0 International License (http://creativecommons.org/licenses/by/4.0/), which permits use, sharing, adaptation, distribution and reproduction in any medium or format, as long as you give appropriate credit to the original author(s) and the source, provide a link to the Creative Commons licence and indicate if changes were made.

The images or other third party material in this chapter are included in the chapter's Creative Commons licence, unless indicated otherwise in a credit line to the material. If material is not included in the chapter's Creative Commons licence and your intended use is not permitted by statutory regulation or exceeds the permitted use, you will need to obtain permission directly from the copyright holder.

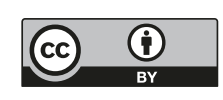

